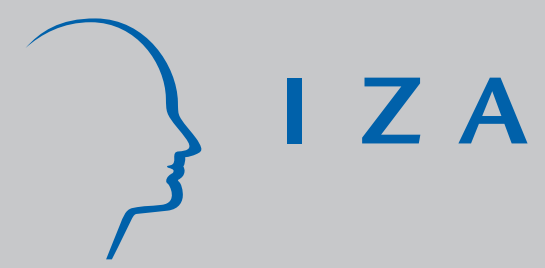

IZA DP No. 8690

Should I Stay or Should I Go?

Romanian Migrants during Transition and Enlargements

Daniela Andrén

Monica Roman

December 2014

Forschungsinstitut zur Zukunft der Arbeit Institute for the Study of Labor 


\title{
Should I Stay or Should I Go? Romanian Migrants during Transition and Enlargements
}

\author{
Daniela Andrén \\ Örebro University and CELSI \\ Monica Roman \\ Bucharest University of Economic Studies, \\ IZA and CELSI
}

\section{Discussion Paper No. 8690 \\ December 2014}

\author{
IZA \\ P.O. Box 7240 \\ 53072 Bonn \\ Germany \\ Phone: +49-228-3894-0 \\ Fax: +49-228-3894-180 \\ E-mail: iza@iza.org
}

\begin{abstract}
Any opinions expressed here are those of the author(s) and not those of IZA. Research published in this series may include views on policy, but the institute itself takes no institutional policy positions. The IZA research network is committed to the IZA Guiding Principles of Research Integrity.

The Institute for the Study of Labor (IZA) in Bonn is a local and virtual international research center and a place of communication between science, politics and business. IZA is an independent nonprofit organization supported by Deutsche Post Foundation. The center is associated with the University of Bonn and offers a stimulating research environment through its international network, workshops and conferences, data service, project support, research visits and doctoral program. IZA engages in (i) original and internationally competitive research in all fields of labor economics, (ii) development of policy concepts, and (iii) dissemination of research results and concepts to the interested public.
\end{abstract}

IZA Discussion Papers often represent preliminary work and are circulated to encourage discussion. Citation of such a paper should account for its provisional character. A revised version may be available directly from the author. 


\section{ABSTRACT \\ Should I Stay or Should I Go? Romanian Migrants during Transition and Enlargements}

The change in Romanian political regime in 1989 has lifted the barriers for population circulation and mobility that were further more amplified in 2002 by the liberalization of Romanians' circulation in the Schengen space. In such context, the aim of this paper is to analyze to what extent Romania's accession to the EU in 2007 has added new features to the Romanian migration phenomenon. Therefore, the paper describes characteristics of Romanian labor migration and its labor market outcomes in the context of the EU second enlargement, covering the recent trends and characteristics, as well as the effects on the receiving and origin countries. The restructuring process that accompanied a painful economic transition created severe disequilibria on the labor market, generating a crisis that remains ongoing. From this perspective, migration was and still is the population's response to this crisis and at the same time reduces the unemployment pressure on the Romanian government. Furthermore, in the new context of financial European crisis, the migration outflows didn't reverse and most migrants prefer to develop adjustment strategies in their destination countries. Romania's accession to the EU in 2007 did not generally change the previous characteristics of Romanian migration. However, one of the key features of Romanian migration would be the new wave of the labor mobility of professionals with impacts upon Romanian economy and society.

JEL Classification: F22, F24, J15

Keywords: international migration, Romania, EU eastern enlargement, transition, Great Recession

Corresponding author:

Monica Roman

The Bucharest University of Economic Studies

6 Piata Romana

Bucharest 010374

Romania

E-mail: monica.roman@csie.ase.ro

\footnotetext{
* Forthcoming in: Kahanec, M., and Zimmermann, K.F. (eds.), "Labor Migration, EU Enlargement, and the Great Recession".

The authors are grateful to Klaus F. Zimmermann and Martin Kahanec, as well as the anonymous referee for providing a number of suggestions that helped to improve the paper significantly. We thank the participants at the 5th IZA/CEUR Workshop on EU Enlargement and the Labor Markets: Migration, Crisis and Adjustment in an Enlarged $E(M) U$ II, for useful comments and feedback. We remain responsible for any mistakes still present.
} 


\section{Introduction}

Before the collapse of its communist regime in December 1989, Romania had been one of the most closed Eastern European countries, resulting in several demographic, economic, social and political characteristics referred to as the initial conditions. These are used to explain some of the differences in performances and behavior when comparing Romania and/or Romanians to their ex-communist peer countries from Europe. Although Romania became the first country in Central and Eastern Europe to establish relations with the European Community in $1974,{ }^{1}$ together with Bulgaria, it was not invited to join the European Union in 2004, when eight former socialist countries from Central and Eastern Europe became EU member states (i.e., the EU8 countries). However, there is no systematic evidence that Romania or Bulgaria (i.e., the EU2 countries) have been backsliding or that their trajectories differ significantly from the EU8 countries (Levitz and Pop-Eleches, 2010).

Despite the lack of evidence that EU2 countries abandoned or reversed their reforms, there are several other differences that affected these two countries in terms of their EU integration: Romanians and Bulgarians had to wait three years to gain access to EU funding and increased links between new and old EU members, including opportunities for Eastern Europeans to work and travel in Western Europe. Additionally, the negative outcomes of the first-wave entrants might have also had a negative effect. Therefore, the large inflows of immigrants from the EU-8 countries along with the negative outcomes from early 2004, ${ }^{2}$ confirm the EU-15 states' concerns

\footnotetext{
${ }^{1}$ We refer, for instance, to the Generalized System of Preferences Agreement in 1974 and an Agreement on Industrial Products in 1980.

21.2 million workers migrated between 2004 and 2007 from Eastern Europe to the UK (770,000), Ireland $(416,000)$ and Sweden $(19,000)$, and emigration had a significant impact on the wage structure, particularly on the wage distribution between old and young workers. (Elsner, 2011).
} 
about the potential negative migration consequences on their labor markets and welfare systems. ${ }^{3}$ However, many Romanians left Romania to work abroad after the first enlargement, and consequently Romanians became the group of non-nationals living in the EU with the most significant increase during the period from 2001 to 2010, with their numbers increasing seven-fold from 0.3 million in 2001 to 2.1 million by 2010 (Eurostat, 2011).

There is great uncertainty about the exact numbers of Romanian migrants reported by the official statistics, and the existing aggregate data hides the considerable variation in the selection patterns across destination countries, while previous studies offer almost no information that can be used to identify the underlying factors that explain this variation. ${ }^{4}$ Fortunately, interest in the migration issue is increasing in Romania, with several institutions providing information and data sources ${ }^{5}$ that could be used to describe both the characteristics of Romanian migrants and returnees as well as also their attitudes and behavior. For example, using such data from the Public Opinion Barometer of the Open Society Foundation (surveys from 2001 and 2004) and official sources (2002 census, vital statistics), Sandu (2005) examined the general dynamics of temporary emigration in post-1989 Romania, while he also used data on migration intention and selectivity to study migration as a life strategy. In order to examine the key patterns of temporary emigration from Romania after 2000, Sandu (2007) combines data from the 2002 census and several waves of the Public Opinion Barometer (POB) of Open Society Foundation (OSF) from the period 2001-2004.

\footnotetext{
${ }^{3}$ Even though Freedom of Movement, a basic principle of the EU, guarantees every worker from the New Member States the right to migrate to any EU country and take up employment, in practice only Ireland, the UK and Sweden immediately opened their labor markets in 2004.

${ }^{4}$ Data concerning permanent emigration is officially released in the statistical yearbooks, and "official data on the dynamics of temporary emigration are very limited" (Sandu, 2007).

${ }^{5}$ The Migration and Development Program was launched by the Soros Foundation in Bucharest in 2006, specifically in the context of the integration of Romania in the European Union, which aimed to find out the general characteristics of Romanian migration (2006) or to estimate the effect of temporary immigration (2007-2008).
} 
Unfortunately, these data sources do not include natives from the destination country or non-migrants, and thus they cannot be used to analyze the decision to migrate or the performances of Romanian migrants on the labor market in Romania (compared with non-migrants) and/or in the destination countries (in comparison to natives or other migrants). These analyses require a combination of census and survey data in order to identify Romanian migrants in destination countries, as well as matching this information with micro-data on non-migrants and returnees in Romania, as recently undertaken by (Ambrosini et al., 2012). The authors combine several sources of data from Romania and three representative destination countries (US, Spain and Austria) to estimate the economic performance of both Romanian migrants and returnees. $^{6}$

Based on the facts and results from earlier literature on Romanian migration, this chapter aims to offer a perspective on some significant trends of Romanian migration before and after the second EU enlargement, as well as the Romanian migrants' labor market outcomes in representative destination countries. The second section briefly describes the economic, social and demographic context in Romania, considered relevant for understanding the causes of large Romanian migration over recent years. Section three presents the dynamics and waves of Romanian migration, offering a profile of Romanian migrants. In section four, the labor market outcomes of Romanian migrants in receiving countries are detailed. Section five describes the return migration patterns and effects of the recent financial crisis, while section six presents two of the most relevant features of Romanian migration, namely remittances and brain drain. The final section concludes the chapter.

\footnotetext{
${ }^{6}$ Ambrosini et al. (2012) analyzed the rationality of decisions to migrate and return with regard to the observed selectivity patterns and the sorting of Romanian migrants across three destinations: the US, Spain and Austria. Based on a combination of four observable characteristics (education, age, gender, family type) they created 320 cells to estimate their wage-earning ability and their probability of employment (in Romania). For each cell, they count non-migrants, returnees and migrants to the US, Austria and Spain to determine how these groups compare to each other in their distribution across skills.
} 


\section{Economic and demographic context in Romania after 2000: a brief description}

After the socialist economic system from Eastern Europe was replaced by the capitalist model in 1989, the economic activity and real output in these countries severely decreased, albeit with different intensities. Unlike the former socialist countries from Central and Eastern Europe, the transition process in Romania was accompanied by a persistent recession until 2000. For almost a decade from 2000, an uninterrupted economic growth followed (Figure 1), although this was accompanied by a widening current account deficit and a slowdown of disinflation. Despite the overall evolution of the economy being positive, a strong decrease in growth of $7.1 \%$ occurred in 2009 , in the context of the global financial crisis. The Romanian government has adopted a series of measures to maintain the macroeconomic stability in the context of a European economic environment that was becoming increasingly volatile. While several anticrisis measures, including reducing wages in the public sector by $25 \%$ and increasing the VAT from $19 \%$ to $24 \%$, had a strong social impact, they also reduced the long term effects of the crisis.

$<<<$ Figure 1 about here $>>>$

Characterized by the large size of the informal economy, ${ }^{7}$ the macroeconomic environment was not only affected by the structural transformations, but also by the significant changes in the labor market composition. Owing to mass emigration to Spain and Italy, the registered unemployment rate was moderate, although some specific characteristics of the unemployed population emphasise the existence of the labor

\footnotetext{
${ }^{7}$ According to National Institute of Statistics (2009) data, between 1.4 and 1.7 million persons work in informal economy.
} 
market rigidities. The young population was severely affected, with the youth unemployment rate at $23.7 \%$ in 2011 (Eurostat data. 2012). At the same time, long-term unemployment rates have been slowly increasing, with the share of long-term unemployed still at an acceptable level (3.1\%), lower than the European average. Behind these figures, the Romanian labor market is highly unbalanced and could be perceived as two different segments that are specific to urban and rural areas. While the labor market in urban areas is in line with the European model, in rural Romania the labor force has a specific structure for agricultural economies: the share of the population that is economically active in agriculture is $28 \%$, more than five times the European level (National Institute of Statistics 2012a).

The process of de-industrialization and the labor market crisis prompted a switch from a rural to urban internal migration type in early1990s to a significant return urban to rural migration. These returnees became active in agriculture, predominantly in subsistence farming, but also faced a lack of economic opportunities in the villages. The characteristics of this internal flow significantly affected the innovative circular or transnational migration, in the sense that villages with high urban-rural immigration rates recorded a higher propensity for circulatory migration abroad (Sandu, 2005). ${ }^{8}$

The economic fluctuations and structural adjustments specific to the transition period had a strong impact on Romanians’ living standards and contributed to rising poverty. According to Eurostat data, the relative poverty rate in Romania peaked at 24.7\% in 2007, much higher than 18.5\%, the level reported by Panduru et al. (2009).

In 2010, 22\% of Romania's total population was considered at-risk-of-poverty (the highest rate in the EU). ${ }^{9}$ However, this rate differed significantly according to the individual occupational status: $17 \%$ for employed persons, $45 \%$ for unemployed people

\footnotetext{
${ }^{8}$ Sandu (2005), focuses on the particular case of migrants from Romanian villages to foreign countries and describes the circular migration outside Romania, as a particular type of temporary migration during the period 1990-2001.

${ }^{9}$ Disposable income was below $60 \%$ of the national average, after social security transfers.
} 
and $10 \%$ for retirees. While these figures describe the poverty rates with respect to a fixed threshold, considering the relative poverty threshold, as in Panduru et al. (2009), a sharp decrease in the poverty rate after 2000 is noted: the poverty rate expressed relative to the 2004 threshold was $9.8 \%$ in 2007 , compared to $31.2 \%$ in 2000 . However, poverty and the lack of economic support continue to remain important factors pushing people to migrate to more favorable regions for work.

Despite Romania being sheltered by its high underground economy, the highest poverty rate in the EU and an intense labor migration, the economic crisis has not been particularly dramatic in Romania in 2012. Nonetheless, the country was shocked in 2012 by the political capture of the state, which was manifested in the intense politicization of administration, discretionary law-making and favoritism in public resources allocation (Romanian Academic Society, 2012). The political crisis of 2012 raises several questions about constitutionalism, democracy and the rule of law in Romania, whilst also suggesting that much less attention was paid to helping people to understand and adapt to all changes of the transition. Communist ideology and policies deal with the problem of the state in a different manner; no individual, group or institution escaped the arbitrary intervention of the ruler, in neither the public nor the private sphere. Changing this capital takes time, and this duration might vary across groups of people. In this context, the Romanian diaspora and its magnitude has become an important public and political issue due to its voting power.

The stable population of Romania was around 19 million in 2011 (National Institute of Statistics, 2012), reflecting a decrease of almost four million since 1989. This dramatic decrease can be explained by the major difference between the evolution of birth rate and migration before and after December 1989. If the strictly controlled demographic policy was responsible for both the high fertility rates (due to strict limits on both abortion and contraception) and very low spatial mobility (both internal and 
international migration) prior to December 1989, the population's dynamics and structure was mostly affected by the numerous changes taking place within the Romanian society that gave all individuals the freedom to decide about their family structure and where to live. Consequently, fewer children have been born after 1990 and relatively large flows of individuals have started to migrate temporarily or permanently. Both the reduction in the population's growth rate and its absolute decline has significantly changed the age structure of the population, speeding up the demographic ageing. Many of today's pensioners started their dependency on social insurance as earlier retirees of the 1990s. ${ }^{10}$ While this involved obvious benefits for relatively old workers who theoretically had the highest risk of experiencing unemployment, (almost) unknown until 1989, it discouraged labor participation in the formal labor market and caused deterioration in the balance between contributors and beneficiaries, ${ }^{11}$ leaving the state pension scheme in a state of full-blown deficit. While this situation caused a high propensity for employment in the case of citizens aged over $65,{ }^{12}$ the share of the active population and activity rates are decreasing for the working age population, owing to the sharp decrease in the number of younger cohorts (i.e. 15-25 years).

The fluctuating economic growth that characterized a painful economic transition period and the restructuring process in Romania were accompanied by severe disequilibria on the labor market, generating a crisis that remains ongoing. In such a context, migration reduces unemployment pressure on the Romanian government. For some rural regions, international labor migration removes the pressure from the local

\footnotetext{
${ }^{10}$ The government not only encouraged workers to retire at the lower threshold of the mandatory retirement ages (60 years for men and 55 years for women), it also allowed early retirement for workers who had worked in a risky work environment and generously granted invalidity pensions (connected to the strong "culture" of buying medical certificates that prove permanent or temporary loss of capacity to work).

${ }^{11}$ In 1990 the pensioner/employee dependency rate was 0.42 , and ten years later the dependency ratio was three times as high, meaning that each employee was supporting 1.32 pensioners.

${ }^{12}$ According to Eurostat (2012) data, the employment rate for people aged more than 65 was 38\% in 2000 and decreased to $13 \%$ in 2010, which was still much higher compared to the European average of $4.7 \%$
} 
labor markets, as well as the burden of the social protection system concerning migrants, who are their potential beneficiaries.

\section{Romanian migrants before and after 2007}

Prior to the second enlargement in 2007, over one third of Romania's households, approximately two and a half million citizens, had at least one member with a foreign labor experience gained during 2000-2006 (Sandu et al., 2006). The paths and structure of outgoing migration are very different across the years, correlating with the economic, social, political and institutional situation in Romania during the transition years, as well as the "initial conditions" described in the previous sections of this chapter. Before the collapse of the Romanian communist regime in December 1989, the official statistics reported very low numbers of emigrants, who were mostly political refugees and/or relatively highly educated Romanians of another ethnicity (Jews, Germans and Hungarians). ${ }^{13}$ The ethnic migration continued into the beginning of the 1990 s (German and Hungarian minorities), with the largest departure flows from areas with a high ethnic concentration. Permanent migration was strongly reduced after 1994, while temporary migration that was mainly due to career opportunities started to increase. During the period 1994-2000, the destination of Romanian migrants became established towards three groups of countries: 1) a positive selection of a rather small yet persistent migration, with a significant share of young people who migrate for educational purposes to more traditional immigration countries (the US, Canada and Australia); 2) a neutral average selectivity, with a higher concentration towards the lower and upper ends of the skill distribution, to continental European countries (Germany, Austria and France); and 3) a negative selection of large flows of lower skilled migrants, often involving informal or illegal employment spells, to Mediterranean countries (mainly

\footnotetext{
${ }^{13}$ For example, in the 1977 census, ethnic Germans only represented 1.6\% of the population, but they constituted 44\% of the emigrant population during 1975-1989.
} 
Spain and Italy, but also to a lesser extent Portugal and Greece) (Ambrosini et al., 2012).

The migration outflows sharply increased in 2002, when Schengen visa restrictions were lifted for Romanian citizens, thereby gaining the right to free circulation within the Schengen area. However, after 2007, the year of the second enlargement, the stock of Romanian migrants in Europe decreased, which might be associated with a decline in the pace of annual departures. The migration outflows were mostly restricted to qualified and highly qualified personnel, referred to as the fourth wave of Romanian migration (Alexe, 2011). However, Romanians were the most mobile migrants in 2008, followed by Poles and Germans, when the EU-27 Member States received nearly two million migrants of other EU nationalities. In 2009, Romanian migrants were the second largest group of non-nationals in the EU-27, representing $6.2 \%$ of the total foreign population (Eurostat, 2011).

Owing to both increased return migration and a decreasing departure rate, a light slowdown of the stock of migrants was registered after the second enlargement. In an increasingly stable profile of international migration, Italy and Spain remained the preferred destination countries. In 2010, Romanian migrants were the most represented foreign group in both Spain (843,775 residing legally) and Italy (968,576 residing legally). These two countries each host around $40 \%$ of Romanian migrants in Europe (see Figure 2), followed by Germany (5.72\%), the UK (3.78\%), Austria (2.23\%), France (2.3\%), Portugal (1.52\%), Greece (1.73\%) and Belgium (1.24\%).

\section{$<<<$ Figure 2 about here $>>>$}

Romanian migration, both before and after the second enlargement, can be characterized as mainly economically driven, with factors such as differences in wages or better economic conditions reflecting the most significant push factors, along with 
several specific factors. Among these, there is the decreasing migration cost, as reflected by the diverse and relatively accessible alternatives to travel and communicate. Furthermore, personal needs and expectations also play an important role in the decision to migrate, as cited in various interviews from Sandu et al. (2006), in which migrants expressed their satisfaction about being respected at their work place. At the same time, geographical distance and linguistic or cultural similarities as well as networks are very important pull factors (Kahanec et al., 2009).

The profile of Romanian migrants is remarkably similar to that simulated by Sandu and De Jong (1996) in the context of the market and democratic transition in the early-1990s. Based upon internal migration survey, census and population register data, Lisrel path models suggest that in terms of migration patterns, the early stages of Romanian transition were typified by the search for places offering the greatest market and democracy returns. Transition migrants can be characterized as young and exhibiting a higher degree of modernity, as revealed by lower life satisfaction, higher cultural consumption, higher support for market and democracy value and lower support for family compared to a job and individual orientation.

In the early 2000s, prior to the second enlargement in 2007, both migrants and returnees were positively selected in respect with the education variable, relative to the total population (Ambrosini et al., 2012). The share of returnees is smallest in the group of people with no university degree (and for migrants with primary school education), while it is largest among those with tertiary education (which is the same for migrants). The selection of migrants seems to be even more skewed towards the highly educated compared to returnees. In terms of age, returnees are much less differentiated from nonmigrants; however, they tend to be slightly over-represented among groups with intermediate and old age rather than young workers (below 25). Relative to non-movers, migrants to the US tend to be both better educated and older, while migrants to Spain 
are lower educated (much more concentrated than non-migrants among workers with only a primary degree) and younger (over-represented in the group of people that are less than 30 years of age). Migrants to Austria are the most similar to non-movers, and are concentrated in intermediate education and age groups.

In 2007, the year of the second enlargement, similar demographic characteristics are observed in the case of Romanian migrants in Spain. This category is particularly important owing to its magnitude in Spain, with Romanians representing the second largest ethnic minority in this country, as well as reflecting the second largest group of Romanian migrants in Europe. The data provided by the National Statistical Institute in Spain through the National Immigrant Survey (in Spanish Encuesta Nacional de Inmigrantes) confirms the balanced gender distribution, with a slight advantage for women (see Table A1 in the Appendix). The Romanian migrants in Spain are young, with the average age being 33 years, and two thirds of them have graduated from secondary education. In terms of marital status, more than half of the migrants are married. The labor market situation of Romanians in Spain reflects the large shares of employees (77\%), but also the significant shares of unemployed persons (15\%). For those employed, the majority have fixed-term contracts and the average income was 933 euro. In the case of Italy, the other destination country that attracts Romanian migrants, migration was mainly driven by women during 2001-2008, while the more recent postenlargement trend shows that more Romanian men migrate to Italy (Mara, 2012). Despite much concern about the children left at home, some studies emphasize the family type of Romanian migration; in Italy, $87 \%$ of early comers live with their partners; around $50 \%$ of them have children in Italy, who live with them in $80 \%$ of cases (Mara, 2012), and in Spain, around 67\% of those interviewed reported that they came with their family, or part of it (Marcu, 2010). 
Romania's accession to the EU in 2007 did not generally change the characteristics of Romanian migration. However, it is possible to identify some key features of Romanian migrants compared to migrants from other countries with high levels of migration from the Balkan region by using the results from the summary report of IASCI-Soros Foundation Romania's (2010) research overview. ${ }^{14}$ Romanian migrants maintained the balanced gender distribution and are young (34.6 years), with a large proportion of them having a medium level of education (86\%), while $12 \%$ are higher educated.

\section{Labor market outcomes of Romanian migrants in receiving countries}

The educational level of Romanian migrants has significantly changed over time, owing to the selection into migration as well as several major reforms of the Romanian educational system during the communist regime and transition years. Romanian migrants in the working age group should be expected to have at least ten years of education (if born after the 1960s) or good vocational training and experience in occupations connected to heavy industries and/or construction (if born before the 1960s). However, the occupational skills are not sufficient for migrants' integration into the labor market; for many occupations, a relatively good knowledge of the language spoken in the country of destination is required. This might initiate a selection towards occupations that have a much lighter or no language requirement, which would explain the distribution of Romanian migrant workers by groups of occupation and destination countries after the second enlargement (Figure 3). Even though we do not have data to control whether the difference between groups is statistically significant, Figure 3

\footnotetext{
${ }^{14}$ The report is based on two datasets: 1 ) a household survey, based on 1,427 household interviews conducted in August 2010, with 1,130 households with one or more members experiencing long-term migration and 297 households without migration experience. 2) a migrant survey that took place in August and September 2010, covering a sample of 2,901 Romanian citizens working and living abroad for at least 12 months. However, the available reports do not report any information about the samples' representativeness. This is an important detail that should be taking consideration especially for the second sample, which is to a large degree affected by self-selection (interviewed persons are summer vacation returned migrants).
} 
shows that a relatively high proportion (52\%) of all Romanian working migrants have an occupation that requires specialized skills (which might be gained through vocation training), while $39 \%$ have occupations that require very little or no education at all. This last group is the largest (42\%) in south EU countries and lowest (14\%) in the non-EU countries. At the same time, the group of professionals has the highest share in the nonEU countries (24\%) and the lowest in the south EU countries (1\%). Figure 4 suggests that the Romanians who migrated to a non-EU country (mostly USA and Canada) have occupations that require a higher level of education than all other migrants; therefore, we can conclude that they are higher educated compared to those who migrate both to south and north EU countries. Moreover, we can also say that those who migrated to north EU countries are better educated compared to those who migrated to south EU countries.

$<<<$ Figure 3 about here $>>>$

Ambrosini et al. (2012) reported that Romanian migrants and returnees are strongly affected by wage incentives. Countries with a wage structure strongly increasing in skills thus attract the most highly educated immigrants and induce the greatest benefits to their income and productivity. For migrants to Spain, the largest benefits would accrue to the low skilled, while for migrants to the US, those who are highly skilled are more likely to have a higher return. More recent data (covering the years around 2007) shows that the skill distribution of Romanian migrants to Spain seems to be persistent over the years, with around $42.2 \%$ of workers having an unqualified position, $34.5 \%$ are qualified workers in industries and around $11 \%$ work in the service sector (Barbulescu, 2012).

According to Ambrosini et al. (2012), migrants in the US have a wide wage dispersion relative to migrants' wage distribution in Romania, an intermediate one in Austria and the smallest in Spain, smaller even than in Romania. This indicates that 
returns to skills are highest in the US and lowest in Spain, and that the average migration premium is much more substantial for migrants to the US (990 \$ per month) than for migrants to Spain (300 \$ per month). ${ }^{15}$

Romanian migrants are primarily engaged in the same economic sectors as migrants from Albania, Kosovo, Bosnia and Herzegovina and Moldova (Soros, 2011), which include construction (26\%), domestic care (21\%), manufacturing (12\%) and service industries. Given their primary orientation towards south EU countries, a surprisingly low number of respondents are engaged in the agricultural sector (7\%). In particular, there are a high number of migrants engaged in other services (22\%) and health services (11\%) in the non-EU area. It has to be remarked that Romanian women mainly work in domestic care, while women from Bosnia and Herzegovina and Kosovo are more often engaged in manufacturing and services sectors. Romanian migrants have a lower income compared to other Balkan migrants (around 1,100 euro in the case of Romanian migrants from southern European countries, and 1,400 euro in the case of northern European countries). This might be explained by a less mature migration, the country of destination and the employment sector. While, for instance, Bosnia and Herzegovina and Kosovo migration tends to be towards higher income countries in Northern Europe (e.g., Germany, Switzerland, Austria, the Nordic countries), the largest group of Romanians choose an EU member state from Southern Europe as a destination (particularly Italy and Spain), with much smaller groups having migrated to Northern Europe.

A surprisingly high number of Romanian migrants describe themselves as being engaged in the informal sector; most of them are women engaged in domestic care and

\footnotetext{
${ }^{15}$ These results are based on a simple way of characterizing the migration premium across skills by reporting the distribution of the log wages earned by migrants abroad and those wages migrants would have received at home (imputed based on their observable characteristics). Averaging the two distributions using the density of skills of migrants and observing the difference would generate the average migration premium (Ambrosini et al., 2012).
} 
agriculture in the south EU region, but also men engaged in construction. Mara (2012) reported that around $25 \%$ of Romanian migrants in Italy claim not to have a regular working contract, while $60 \%$ of women who worked without a contract have a part-time job, while $16 \%$ of men had no regular working contract. Men earned on average around 1200-1500 Euro per month, whereas women earned around 900-1000 Euro per month. One potential explanation could relate to the gender difference in occupational distribution, as well as the typical roles that women undertake; namely, those who provide services and care at home are normally paid less, partly due to being provided with accommodation and daily living elements. Interestingly, the early comers among men moved to a specific location "to look for work" while the late comers did so because of "taking a job offer". This situation might be the result of the institutional settings in the receiving countries. For example, despite some restrictions of full access to the Italian labor market having been imposed on Romanian (and Bulgarian) workers, they limited overall, while employment in agriculture and tourism, construction and domestic or care services, the metal industry and highly skilled professional activities was not subject to any limitations (Salis, 2012).

In Spain, most Romanians (regardless of gender) arrived prior to the second enlargement without legal status, albeit working, yet their assimilation into both employment and legal status is relatively high (Rodríguez-Planas and Vegas, 2012). As suggested by Rodríguez-Planas and Vegas (2012), the assimilation pattern reflects that employment represents the easiest way of becoming legal in Spain (having an employer guaranteeing a job is one of the main conditions in the amnesties). In 2007, the average monthly wage was around 905 euros for women and approximately 952 euros for men.

In France, Romanians are the largest group among those with permits for economic motives, with around 4,000 entries in 2010 (Devitt, 2012). In 2010, economic immigration from Romania and Bulgaria consisted of over 5,000 permits, with half of 
them for 'employees'. However, access was only permitted for a list of 150 occupations, which corresponded to $40 \%$ of the total of job openings registered by the national employment agency. Most of the jobs on the shortage occupation lists were medium and low skilled.

According to the Migration Advisory Committee Report (2008), Romanian immigrants constitute a small segment of the UK labor market. Acknowledging that the available data are subject to limitations, it shows that relative to some other countries, immigration from Romania to the UK has been low, both before and after the accession. The post-accession immigration to the UK has largely occurred outside of the employer-based permit system. As outlined by Devitt (2012), the increasing stock of Romanian workers (see Figure 2) is possibly explained by the additional flow of new immigrants after the accession in 2007, as well as the regularization of some immigrants who were working in the UK pre-accession. EU-2 migrants in the UK typically work in more skilled occupations than their EU-8 counterparts, strongly including trades such as construction. However, the occupational distribution of EU2-born immigrants in the UK in 2008 is similar to that of the EU8-born immigrants in 2004. Clark and Drinkwater (2008) reported that self-employment was an important route for Bulgarians and Romanians to the UK during 2000-2007, and the access to paid employment was restricted in their case.

\section{Return migration and labor market outcomes in the context of financial crisis}

Until 2007, the literature on Romanian migration sought to explain migration intentions in the context of EU enlargement, reflecting a great interest in capturing the future intentions of Romanians to migrate, as well as observing their return migration.

Using data on Romanian non-migrants, migrants and returnees from 2003, Ambrosini et al. (2012) reported that around half of Romanians who migrate do return. 
Returnees are positively selected among education groups versus non-migrants and they are selected in a similar way as migrants to the countries with the highest skill premium (such as the US). ${ }^{16}$ Both types of selection (either to migrate or to migrate and return) are consistent with the idea that workers move in accordance with their wage premium received. As highlighted by Shima (2010), the returnees' relative distribution is much more skewed towards workers with tertiary education, at the expense of those in any other education group. Returnees are much less differentiated from non-migrants in terms of age, despite being slightly over-represented among intermediate and old age groups, as opposed to among young workers (below 25). On average, returnees earned $12-14 \%$ more than similar people who stayed at home, which might be explained by migrants returning home with skills that would have been hard to pick up had they never gone abroad.

Based on a similar analysis that simultaneously counted for the decision to return and labor market participation, Shima (2010) concluded that the negative selectivity among the returnees, the circulatory migration intentions versus the permanent return of migrants and the labor market structure were the main determinants eroding the upgrading in terms of employment and occupational status in 2005. Indeed, such factors do not really pay off for the returnees, with respect to occupation and wage premiums.

Following the second EU enlargement, Romanian migrants’ intentions to stay in their destination country or return to Romania had a significant impact on the labor market in both the receiving and sending countries. Return migration is becoming more relevant in the context of the financial crisis across Europe, given that it severely affected the countries with the largest shares of Romanian migrants, namely Spain and

\footnotetext{
${ }^{16}$ The authors define the selection of migrants (positive or negative) as the difference in average skills between migrants and non-migrants. They call the wage-earning ability the skill of that group of workers.
} 
Italy. Although the economic crisis has not caused a wave of mass return of the Romanians working abroad, those who have returned are only likely to stay for a short period. Bernat and Viruela (2007) reported that immigration flows from Romania have fallen in the Spanish area of Castelló, where employment has fallen by $20 \%$ in just three years (due the effects of the international economic crisis), while the numbers leaving has increased and migration plans have been modified. Nonetheless, the immigrant stock has not fallen significantly, largely owing to continued family reunification. The fact that returning migrant numbers remain moderate and migratory circulation has increased during these difficult years might be explained by the differential between the Spanish and Romanian welfare states, the extent of host society adaptation and the strategies employed by the immigrants. Stanculescu et al. (2012) reported that one of the adjustment strategies was the high flexibility of the changing work sector (with a considerable increase of Romanians working in agriculture), and a decreasing territorial mobility (which was considerably lower than for migrants of other nationalities). Interestingly, the entrepreneurship initiative of Romanian migrants in Italy is increasing: the number of companies belonging to Romanian citizens in 2009 totaled 32,452, increasing by more than $15 \%$ compared to the preceding year. In both Italy and Spain, Romanian migrant women were less affected by unemployment compared to men, which is a consequence of the concentration of women in sectors that are less responsive to economic fluctuations.

According to the results of the IASCI- Soros Foundation Romania's (2010) research overview, three years after the second enlargement, less than half of the interviewed migrants (41\%) reported their intention to permanently return to Romania. Indeed, this is considerably lower than the expectation of the migrants' households in Romania, given that around 53\% of interviewed households reported that their members abroad would return permanently at some point in the future. The household expectation 
was relatively higher (59\%) for the households receiving remittances, compared to nonreceiving households (45\%). The remitting behavior and return intentions are positively correlated in the sense that migrants with a higher propensity to remit are more connected to Romania and consequently generate higher expectations to return. However, these figures might be affected by the nature of the sample, which is strongly affected by self-selection (interviewed persons are summer vacation returned migrants).

The intention to return varies across the country of destination, with a higher interest to return (43\%) among migrants in south EU countries than those in north EU (38\%) and non-EU countries (32\%) (see Figure 4).

\section{$<<<$ Figure 4 about here $>>>$}

In the same study, $48 \%$ of migrant households reported being affected by the ongoing economic crisis to some degree, with the main reason being increasing unemployment in south EU and non-EU regions (around10\%, against 7\% in north EU countries), the full unemployment of other household members in non-EU countries (13\%, against $4.2 \%$ in north EU countries), and a decrease in the labor supply in north EU countries. The search for other employment and/or living on household budgets in the place of migration seems to be preferred, rather than returning either temporarily or permanently to Romania. Indeed, even under such constrains, decreasing or eliminating the remittances is less preferred. However, the level of remittances has decreased over the last few years, ${ }^{17}$ as reflected by the expectations of the household members left in Romania. Around $23 \%$ of households with migrants in south EU countries (and receiving remittances) expect to receive less in the next 12 months compared to the previous 12 months.

\footnotetext{
${ }^{17}$ This decrease was more visible for the number of remittances coming from the decrease in the south EU region (26\%) than in the north EU (17\%) or non-EU (7\%) countries. As Romanian migrants in the south EU countries are largely sent from Spain and Italy, this implies a significant drop in overall remittance values to the country (Soros, 2011b).
} 
Romanian migrants' likelihood to permanently return is lower compared to circulatory or seasonal migration (Barbulescu, 2009; Marcu, 2010), and is positively correlated with (more) education and entrepreneurship intention upon their return (Shima, 2010). Furthermore, the return decision is also affected by the prospects of a lower wage, fewer opportunities to find a better-paid occupation or job and greater difficulties in setting up an entrepreneurial activity looming and limiting return choices (Ferri and Rainero, 2010).

The possible effects of migration experience on economic performance are accompanied by the impacts on returnees’ human capital. Badescu (2010) identifies important differences between returnees and "other people" that may be attributed to labor migration. Optimism and social trust are significantly higher for people in their forties who have worked abroad than for other people. Moreover, younger people who have worked abroad show less social trust than those without migration experience. At the same time, there were no significant differences in terms of variables that describe the quality of citizenship, given that people who have worked abroad are no better or worse off than others in terms of most measures of political culture. ${ }^{18}$

\section{Relevant impacts of Romanian migration on the origin country}

\subsection{Remittances}

The sharply increasing remittance inflow after 2004 marked Romania as one of the top recipients of remittances worldwide, holding the fourth position in respect with the absolute level of transfers in 2008, accounting for 3.3\% in terms of GDP (World Bank, 2011). However, as in most developing countries, the official data on remittances for Romania underestimates the real dimension of the transfers. Lazaroiu and Alexandru

\footnotetext{
18 The analysis is based on a pooled sample of 11,221 cases, extracted from four surveys that are representative for the entire adult population in Romania (May 2002, October 2002, October 2003 and May 2004) of the Public Opinion Barometer. About 5\% of the pooled sample (i.e., 427 observations), and of each survey (about 100 observations per survey) worked abroad.
} 
(2008) report that approximately $40 \%$ of the transfers were made through informal channels, including bus drivers operating on international lines, as well as via family members, friends and relatives. Moreover, the cost of sending money through formal channels has declined recent years, while the financial and banking culture the senders and receivers having increased, thus rendering formal transfers more appealing. Romanian migrants mainly use money transfer operators such as Western Union and Money Gram, but also banks, credit unions and postal offices in both sending and receiving countries. ${ }^{19}$

The increasing remittance inflows have sustained domestic consumption and economic growth, while reducing the current account deficits. During 2001-2003, the volume of remittances was estimated at US $\$ 1.5$ to 2 billion per year, which is equal to or even exceeds the foreign investment volume (Lazaroiu, 2004). Remittances reached a peak of US $\$ 9.4$ billion in 2008, yet halved in the following two years, owing to the economic crisis and slow recovery. According to National Bank of Romania (2010), the private transfers balance displayed a surplus of EUR 2,800 million in 2010, which was down 17.4 percent from 2009, on account of “workers' remittances”. ${ }^{20}$ However, these numbers differ dramatically from those in Soros (2011), which reported that the total estimated pool of 'retained savings' in the 12 months prior to September 2010 was almost 12 billion Euro. ${ }^{21}$ According to the same source, Romanian migrants had the highest level of non-remitters in the region (with around $40 \%$ of households not

\footnotetext{
${ }^{19}$ A useful tool for the Romanian citizens working in Italy is the portal created by the Italian Ministry for Foreign Affairs, which started in January 2010 that makes it possible to compare the costs of different operators from money transfer domains, money sent from Italy to other countries (Feraru, 2010).

${ }^{20}$ Out of EUR 2,800 million worth of total net private transfers, remittances from abroad (mainly from Italy, Spain, the USA, Greece, Germany, and the United Kingdom) accounted for 78.5 per cent.

${ }^{21}$ The average amount of remittances sent to Romania is about 2,000 Euro per year (with about 1,670 Euro from non-EU countries, 2,139 Euro from north EU countries, and 2,188 Euro from south EU countries). The aforementioned low income and expenditure level, combined with a mid-range remittance value, is reflected in a mid-range Remittance to Savings Factor of 4.2:1 for Romania. This factor falls to just below that of Bosnia and Herzegovina (4.5:1), yet is almost four times the level in Moldova (1.2:1) (Soros, 2011b).
} 
remitting at all). There is a clear trend that relatively new migrants are more likely to transfer money to their households in Romania than those who left Romania in 2000 or earlier, and migrants residing in an EU state in southern Europe are more likely to remit (63\%) that those in a north EU state (55\%). Differences in remittances from the (three) migration regions are also evident in the purposes of transfer. For instance, while migrants in non-EU and north EU countries primarily remit to support their household members' consumption in Romania, home investments and savings reflect the main remittance purpose for migrants in south EU countries (31\%).

The main destination of remittances is the households' consumption (around 65\%), with approximately 35\% directed to investments and savings. In urban areas, around $22 \%$ of the households receiving money from abroad invest the money in the education and health of their children, in building a house (11\%), starting a business (4\%), purchasing equipment (3\%) and buying land (3\%) (Open Society Foundation, 2006). The decreasing poverty and increasing quality of housing associated with remittances and labor migration also contribute to modernization of Romanian society (Sandu, 2010).

To conclude, given the size and importance of Romanian emigrants’ remittances for the receiving households and the economy as a whole, the positive economic effects of remittances in the context of global financial crisis are not negligible.

\subsection{Brain drain}

Romania is one of the leading European countries affected by brain drain, having faced a large exodus of specialists both before and after the collapse of the communist regime in 1989. Prior to 1989, and indeed during the first year of the transition, the migration might be characterized by a strong brain drain component: the very small flows of relatively highly educated German, Hungarian and Jewish emigrants were expected to 
find a good match in the labor market in the country of destination (the US and Germany). ${ }^{22}$ Starting in 2001, Romania was confronted with both brain drain (highly skilled individuals having a return proportionate to their skills in the destination country) and brain waste (highly skilled individuals who, despite comparatively better wages or living conditions in the country of destination, work in an occupation that requires lower skills). Analyzing the deskilling process in Romanian communities from Spain, Sandu et al. (2009) demonstrates that more Romanian migrants worked as unqualified workers in Madrid compared to their previous position in Romania, (11\% vs. 9\%), while the share of those with intellectual occupations decreased from $4 \%$ in Romania to $1 \%$ in Spain. Romanian migrants living in Italy have also been subject to a gender-neutral deskilling process, affecting women mostly employed in domestic sector, as well as men in construction or agriculture.

The current developments and characteristics of the Romanian labor migration following Romania's adhesion to the EU lead researchers to discuss a new wave of Romanian migration characterized by "the labor mobility of professionals in the context of the economic and financial crisis which seems to form the bases for the migration of qualified and highly qualified personnel” (Alexe, 2011). This last wave contains temporary migrant workers who are using cards and banking accounts, which significantly changes the behavior regarding remittances; moreover, they attempted to leave the country they moved to with the entire family tagging along, have a higher capacity for integration in the country of destination, and the labor migration may become permanent migration. According to a study conducted by the Romanian National Research Institute for Labor and Social Protection (2006), highly skilled

\footnotetext{
${ }^{22}$ The skilled labor force that emigrated from Romania in 1990 most frequently headed towards the USA (10.37\%), Hungary (4.86\%), Canada (4.56\%), France (1.58\%) and Austria (0.29\%). The skilled labor force that emigrated in 2000 mostly headed towards the USA (10.53\%), Canada (6.44\%), Germany (3.75\%), Hungary (3.10\%), France (1.68\%), Italy (0.91\%), Austria (0.70\%) and Spain $(0.52 \%)$. (OECD, 2011).
} 
migration seems to affect researchers, high-tech specialists and health care personnel in particular, which as a group of occupations has already witnessed shortages. Recent attention has mainly focused on medical brain drain, which, if not stopped, is expected to have negative effects on the health and life quality of a population. The share of Romanian doctors that emigrated between 1991 and 2004 increased from 3.94\% to 9.54\% (World Bank data), and this upward trend continued after Romania’s accession to the EU, mainly due to inadequate working conditions, a lack of reasonable incentives and an unsatisfactory career development system (Galan et al., 2011), as well as the overloading of the remaining staff with extra tasks (Rotila, 2008). Moreover, some additional disincentives for health professionals were introduced in 2010, including a $25 \%$ salary decrease and reductions in staff numbers. The preferred destinations for Romanian physicians are France, Germany and the United Kingdom, given that they have active policies in recruiting external personnel, including from Romania. The most popular specializations in these countries are general medicine, intensive therapy and psychiatry.

Even though debates about policies to encourage the educated youth to return to their country have existed since the 1990s, a large difference remains between the theory and practice: it is possible to find several policy measures, yet almost impossible to evaluate whether they have worked. For example, several programs aimed to inform the specialists abroad about the career opportunities in the country, to assist the reinstatement of those returning to Romania, to offer various facilities for those returning to Romania in order to open a business, to modernize the infrastructure in education and research, etc. ${ }^{23}$ However, there is no clear evidence on the effectiveness of such programs.

\footnotetext{
${ }^{23}$ A special Scholarship project intended for students wishing to undertake academic studies in a PhD or a Master degree at a foreign university, on the condition that they return to the country to work in a position
} 


\section{Conclusions}

This chapter depicts the story of Romanian labor migration and its labor market outcomes in the context of the EU second enlargement, covering the recent trends and characteristics, as well as the (positive and negative) effects on the receiving and origin countries.

Research of migration is intrinsically interdisciplinary, and consequently there is no single theory accepted by social scientists in terms of the migration phenomenon. The Romanian migration has several of its own characteristics that are not always easily incorporated within theoretical frameworks explaining out-migration. However, it seems that most of the existing studies on Romanian migration contain components of the new economics of migration (Stark and Bloom, 1985) and segmented labor-market theory (Piore, 1979), which have both contributed to an understanding of international migration.

The magnitude and features of Romanian migration have their roots in the initial conditions of economic, social and political nature. Therefore, despite a decade of positive economic growth, the instable economic environment and labor market crisis corroborated with regional development differences and the persistent poverty create a bundle of factors that have pushed Romanians into a mass labor migration. At the time of the second enlargement, the stock of Romanian migrants in European countries was already sufficiently large to rank Romania among the top European sending countries. The estimate of Romanian migrants in Europe varies between 2.2 and 3 million, with the distribution by destinations showing great concentrations in Spain and Italy. New trends have been identified since 2007, with the migration rates to southern Europe having diminished, while the outflows to north EU countries (Germany and the UK)

in public administration, according to the obtained qualifications, for a defined period of time (one year minimum). 
have become more important. Considering the Romanian migrant profile, it has a remarkable stability in the years before and after the second enlargement: they are young, more than half are married and two thirds of them have graduated from the secondary level of education.

Romanian labor migration has mixed effects on the country of origin. The migrants' exodus generates a dramatic demographic decrease, accelerating demographic ageing yet also decreasing birth rate, given that the female migrants are not only of working age, but also of fertility age.

There are positive effects in terms of labor market outcomes at the macroeconomic level, with labor migration releasing unemployment pressure. The largest economic benefit of international migration is in the form of a "migration premium" for migrants, whereby migration may lead to a more productive pairing of people's skills and jobs. Some of the emigrant workers would have been jobless had they stayed. Rather being dependent on unemployment and/or welfare insurances, they flew back to Romania in the most direct manner possible through their remittances. The results of the study by Ambrosini et al. (2012) suggest that relatively high rates of temporary migration might have positive long-term effects on average skills and wages for a source country such as Romania. At the same time, the brain drain phenomenon generates negative effects in the short run. Therefore, labor shortages in specific professional categories, such as doctors, has already rendered severe consequences upon the Romanian healthcare system.

The economic crisis covering Europe after 2008 adds new dimensions to the migration issue. Will Romanian migrants in Europe return to Romania, will they remain in destination countries or will they try to find new destinations? The evidence shows that the recent financial crisis has not reversed the migration outflow, and less than half of the Romanians working abroad reported having plans to permanently return home in 
the future. Even if they are affected by crisis, their adjustment strategies are connected with the new receiving countries rather than the origins.

Bearing in mind the latest developments in terms of diaspora policies, Romanians working abroad are currently not only perceived as potential voters or promoters of Romanian culture, but also as a labor supply that can help to satisfy declining supply in certain sectors of the Romanian labor market. Unfortunately, no policy measures to manage return migration in Romania are being developed at present. With respect to the potential returnees, measures such as signing bilateral cooperation agreements aimed at supporting returnees once back in Romania reflect a prerequisite to render the returning process sustainable.

\section{References}

Alexe, I. (coord.) (2011), The fourth wave the brain drain along the route between Romania-the West, Sorors Foundation Romania, Bucharest, Inc.

Ambrosini, J. W., K. Mayr, G. Peri and D. Radu (2012), The Selection of Migrants and Returnees in Romania: Evidence and Long-Run Implications, IZA Discussion Papers No. 6664, Bonn.

Badescu, G. (2004), Romanian labor migration and citizenship, in D. Pop (ed.), New patterns of labor migration in Central and Eastern Europe, Cluj-Napoca: AMM.

Barbulescu, R. (2009), The Economic Crisis and its Effects for Intra-European Movement: Mobility patterns and State responses The Case of Romanians in Spain, in New Times? Economic Crisis, geo-political transformation and the emergent migration order, Centre on Migration, Policy and Society, Annual Conference 2009, University of Oxford.

Bernat, J. S. and R. Viruela (2011), The economic crisis and immigration: Romanian citizens in the ceramic tile district of Castelló (Spain), in Journal of Urban and Regional Analysis 3(1), pp.45-65.

Clark, K. and S. Drinkwater (2008), The labour-market performance of recent migrants, Oxford Review of Economic Policy, 24(3), pp.495-516. 
Devitt, C. (2012), Labour migration governance in contemporary Europe: The case of France, FIERI Working Paper, International and European Forum for Migration Research.

Elsner, B. (2011), Emigration and Wages: The EU Enlargement Experiment, IZA Discussion Paper No. 6111, Bonn.

Eurostat (2011), Migrants in Europe: A statistical portrait of the first and second generation, Eurostat Statistical Books, European Union.

Eurostat (2012), Eurostat News Release, 8/2012.

http://epp.eurostat.ec.europa.eu/cache/ITY_PUBLIC/3-13012012-BP/EN/3-13012012BP-EN.PDF

Feraru, P.D. (2010), Migration and Economic Development Comparative Study: Romania-Italy, Revista Romaneasca pentru Educatie Multidimensionala, 5, pp.55-77.

Ferri, A. and S. Rainero (2010), Survey of European Union and Return Migration Policies: the case of Romanian Migrants, Veneto Lavoro.

Galan, A., V. Olsavszki and C. Vladescu (2011), Emergent challenge of health professional emigration: Romania's accession to the EU, in M. Wismar, C.B Maier, I.A. Glinos, G. Dussault and J. Figueras, J. (eds.), Health Professional Mobility and Health Systems: Evidence from 17 European countries, World Health Organization.

Holland, D., T. Fic, P. Paluchowski, A. Rincon-Aznar and L. Stokes (2011), Labour mobility within the EU, NIESR Working Paper No. 279, London.

IASCI- Soros Foundation Romania (2010), Maximizing the Development Impact of Migration. Romania Survey: Key Findings, International Agency for Source Country Information (IASCI).

Kahanec, M., A. Zaiceva and K.F. Zimmermann (2009), Lessons from Migration after EU Enlargement, IZA Discussion Paper No. 4230, Bonn.

Lăzăroiu, S. (2004), More 'Out' than 'In' at the Crossroads between Europe and the Balkans Migration Trends Selected Applicant Countries, in Migration Trends in Selected Applicant Countries, International Organization for Migration, Vienna.

Lăzăroiu, S. and M. Alexandru (2008), Who is Coming after Who is Leaving? Labour Migration in the Context of Romania's Accession to the EU, Country Report, International Organization for Migration, Geneva.

Levitz, P. and G. Pop-Eleches (2010), Monitoring, Money and Migrants: Countering Post-Accession Backsliding in Bulgaria and Romania, Europe-Asia Studies, 62(3), pp.461-479.

Marcu, S. (2011), Romanian Migration to the Community of Madrid (Spain): Patterns of Mobility and Return, International Journal of Population Research, 2011: 1-13, Hindawi Publishing Corporation. 
Mara I. (2012), Surveying Romanian migrants in Italy before and after the EU Accession: migration plans, labour market features and social inclusion, WIIW Research Report No. 378, Vienna.

Martin, R. and D. Radu (2011), Return Migration: The Experience of Eastern Europe, International Migration (forthcoming).

Migration Advisory Committee Report (2008), The labour market impact of relaxing restrictions on employment in the UK of nationals of Bulgarian and Romanian EU member states.

National Bank of Romania (2010), Balance of Payments 2010.

National Immigrant Survey (2007), National Statistics Institute of Spain, http://www.ine.es/en/inebmenu/mnu_dinamicapob_en.htm

National Institute of Statistics (2009), Economia informală în România în anul 2008, Bucharest.

National Institute of Statistics (2011), Statistical yearbook 2011.

National Institute of Statistics (2012), Preliminary Census Data, Accessed 8 December 2012.

http://www.insse.ro/cms/files\%5Cstatistici\%5Ccomunicate\%5Calte\%5C2012\%5CCom unicat\%20DATE\%20PROVIZORII\%20RPL\%202011.pdf

National Institute of Statistics (2012a), Employment and unemployment in 2011- main results: Household Labour Force Survey (AMIGO). Press release No 89, 17 April 2012. http://www.insse.ro/cms/files/statistici/comunicate/com_anuale/ocupsomaj/somaj_2011e.pdf

National Research Institute for Labor and Social Protection in Romania (2006), Evolution of occupations on Romanian labor market in 2010 perspective, Bucharest: Mediaprint.

OECD (2011), International Migration Outlook, Annual Report, Paris.

Open Society Foundation (2006), Romania Urbana, Bucharest.

Panduru, F., M. Molnar and M. Poenaru (2009), Venituri, inegalitate, sărăcie, in M. Preda (coord.), Riscuri si inechităţi sociale în Romania, Bucharest: Polirom.

Piore, M.J. (1979), Birds of Passage: Migrant Labor in Industrial Societies, New York: Cambridge University Press.

Rodríguez-Planas, N. and R. Vegas (2012), Moroccans', Ecuadorians' and Romanians' Assimilation in Spain, IZA Discussion Paper No. 6542, Bonn.

Romanian Academic Society (2012), The Political Economy of a Constitutional Crisis, Policy Briefs No.60, Bucharest. 
Rotila, V. (2008), “The impact of the migration of health care workers on the countries involved: the Romanian situation”, South-East Europe Review, 1, pp.53 - 77.

Salis, E. (2012), Labour migration governance in contemporary Europe: The case of Italy. FIERI working paper, International and European Forum for Migration Research.

Sandu, D. and G. F. De Jong (1996), Migration in market and democracy transition: Migration intentions and behavior in Romania, Population Research and Policy Review, 15, pp.437-457.

Sandu, D. (2005), Emerging Transnational Migration from Romanian Villages, Current Sociology, 53(4), pp.555-582.

Sandu, D. (2007), Community Selectivity of Temporary Emigration from Romania, Romanian Journal of Population Studies, 1-2, pp.11-45.

Sandu, D. et al. (2006), Living abroad on a Temporary Basis: The Economic Migration of Romanians 1990-2006, Open Society Foundation, Bucharest.

Sandu, D. et al. (2009), Romanian communities in Spain, Soros Foundation Romania, Bucharest.

Sandu, D. (2010), Modernising Romanian society through temporary work abroad, in R. Black et al (eds.), A Continent Moving West?: EU Enlargement and Labour Migration from Central and Eastern Europe, IMISCOE Research: Amsterdam University Press.

Serban, M. (2011), Dinamica migratiei internationale: un exercitiu asupra migratiei romanesti in Spania, Iasi: Lumen.

Shima, I. (2010), Return migration and labour market outcomes of the returnees: Does the return really pay off? The case-study of Romania and Bulgaria, FIW Research Reports 2009/10 No. 07, Vienna.

Stark, O. and D.E. Bloom (1985), The New Economics of Labor Migration, American Economic Review, 75, pp.173-178. 
Figure 1. Romania. Unemployment and real GDP growth rates, 1991-2011

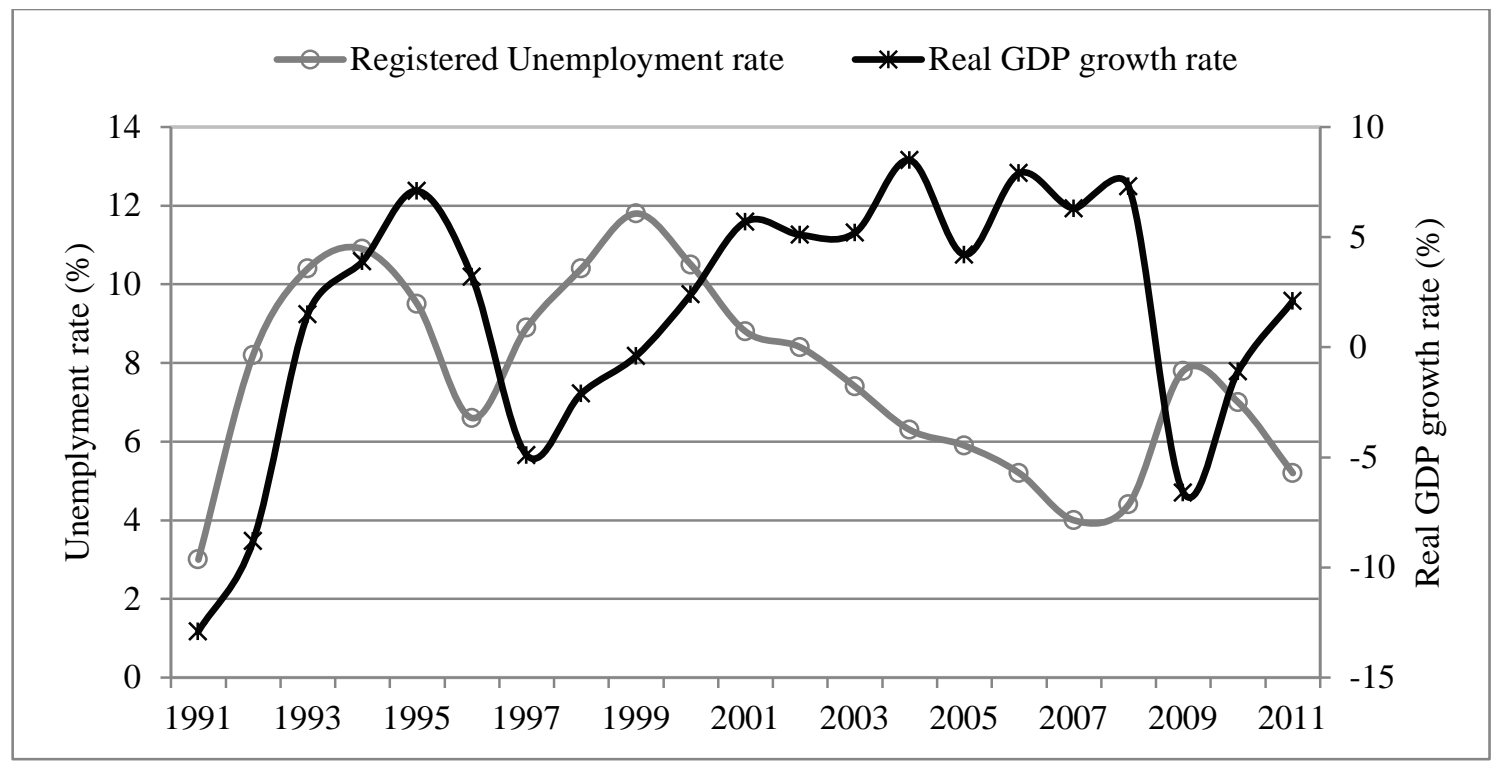

Source: own computation based on National Institute of Statistics data, 2011.

Figure 2. Romanian migrants in selected European countries after 2000

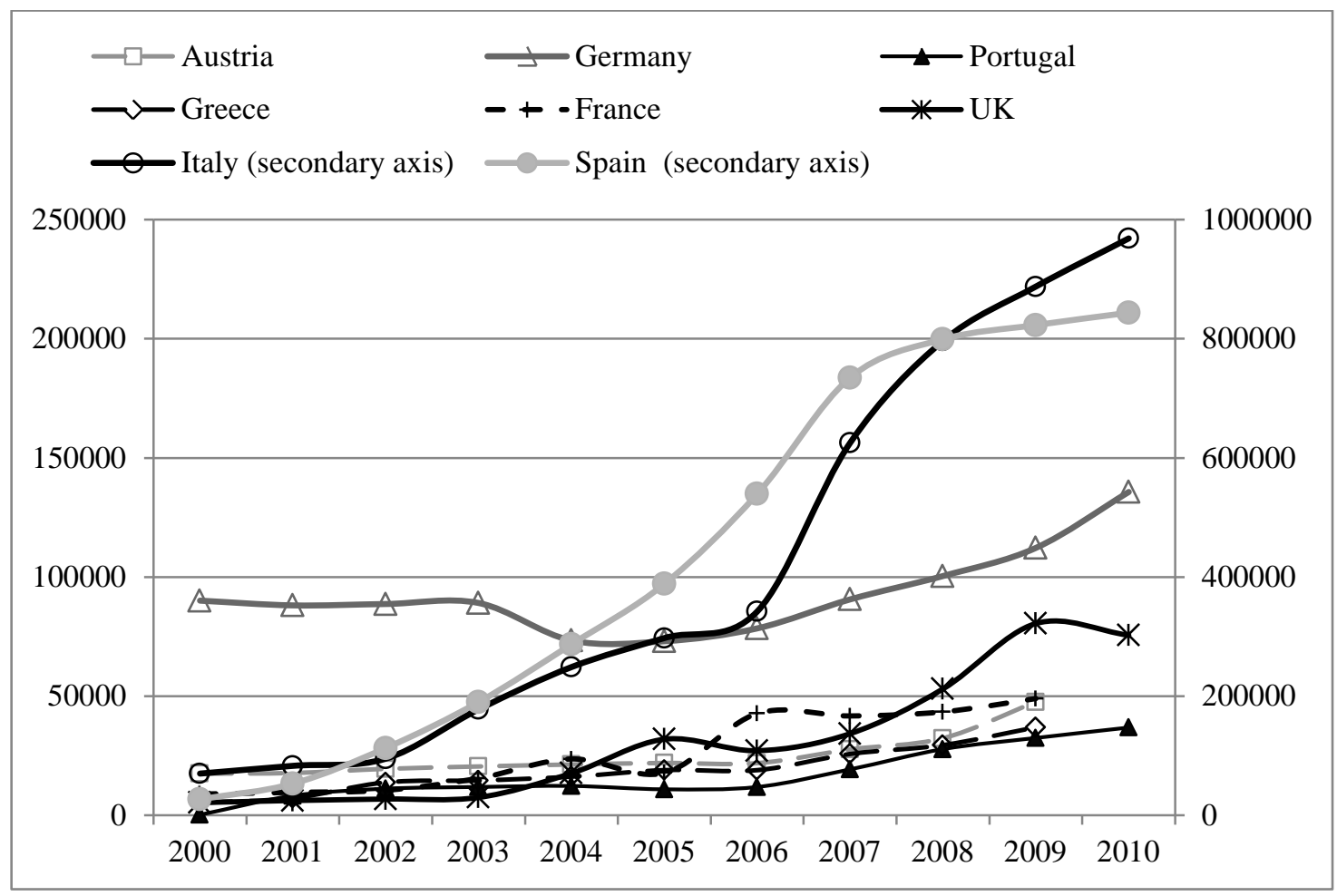

Source: own computations based on data from Holland et al., 2012. 
Figure 3. Distribution of Romanian migrants by occupation and region of destination

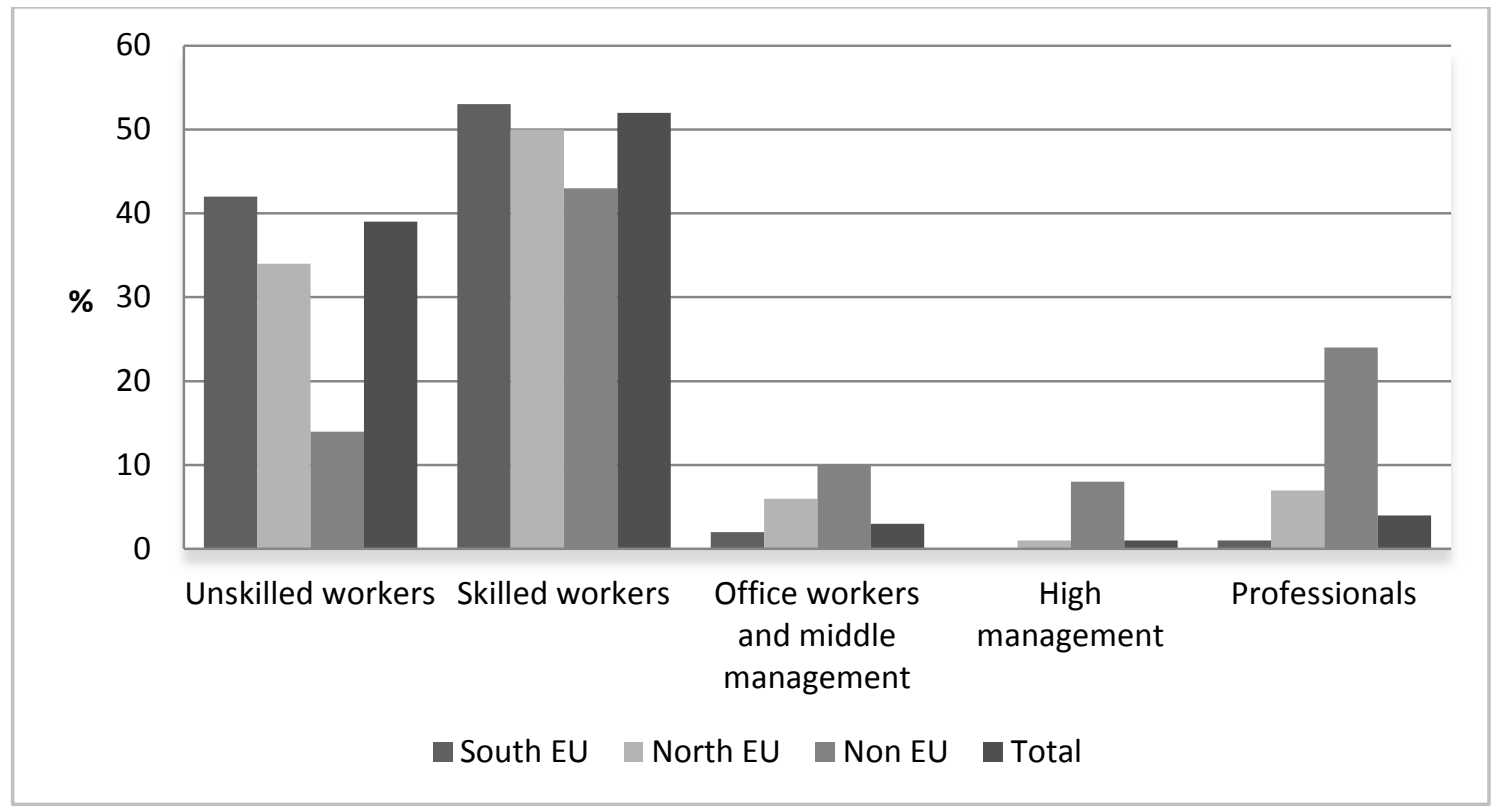

Source: IASCI-Soros Foundation Romania (2010).

Figure 4. Migrants' plans to permanently return to Romania by regions of destination

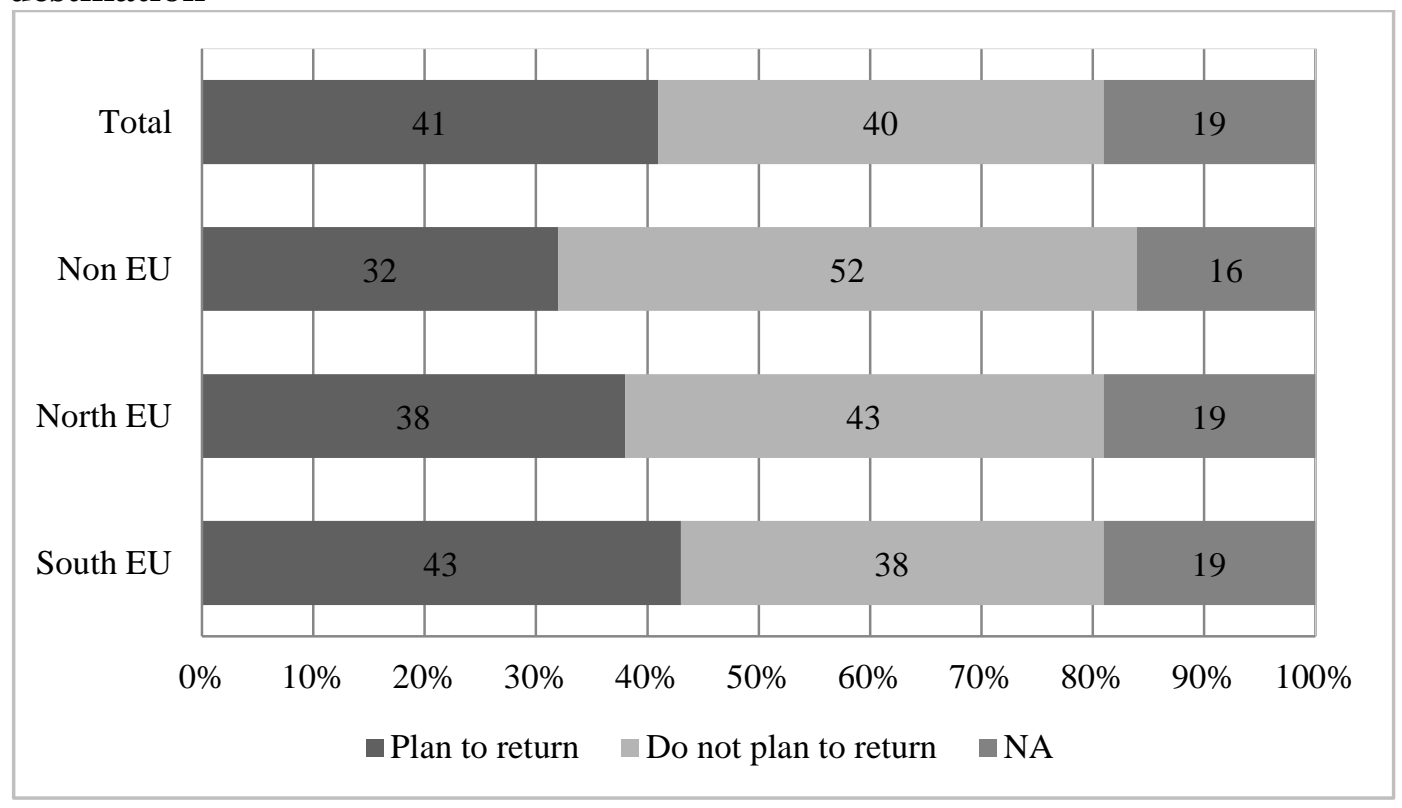

Source: IASCI-Soros Foundation Romania (2010) 


\section{Appendix}

Table A1. Profile of Romanian migrants living in Spain

\begin{tabular}{|c|c|c|}
\hline Characteristic & Values & $\%$ \\
\hline \multirow[t]{2}{*}{ Gender } & Men & 47.2 \\
\hline & Women & 52.8 \\
\hline \multirow[t]{3}{*}{ Education } & Primary school education & 14.6 \\
\hline & Secondary education & 76.5 \\
\hline & Tertiary education & 8.9 \\
\hline \multirow[t]{5}{*}{ Marital status } & Single & 36.7 \\
\hline & Married & 54.8 \\
\hline & Widow & 1.3 \\
\hline & Separated & 2.0 \\
\hline & Divorced & 5.1 \\
\hline \multirow[t]{4}{*}{ Age } & Less than 18 & 2.5 \\
\hline & $18-34$ & 61.1 \\
\hline & $35-54$ & 34.9 \\
\hline & More than 54 & 1.6 \\
\hline \multirow{6}{*}{$\begin{array}{l}\text { Occupational } \\
\text { Status }\end{array}$} & Employee & 77.5 \\
\hline & Self-employed & 6.5 \\
\hline & Unemployed & 15.0 \\
\hline & Student & 0.5 \\
\hline & Retired & 0.3 \\
\hline & Unavailable for work & 0.2 \\
\hline \multirow{6}{*}{$\begin{array}{l}\text { Monthly income } \\
\text { (euros) }\end{array}$} & Less than 499 & 11.4 \\
\hline & $500-999$ & 46.0 \\
\hline & $1000-1499$ & 33.2 \\
\hline & $1500-1999$ & 6.6 \\
\hline & $2000-2999$ & 2.6 \\
\hline & 3000 and more & 0.2 \\
\hline \multirow[t]{2}{*}{ Type of contract } & Temporary employed & 86.7 \\
\hline & Long term employed & 13.3 \\
\hline
\end{tabular}

Source: own processing based on data from National Immigrant Survey (2007), National Statistics Institute of Spain. Un-weighted data. 